\title{
Seasonal contribution of air pollution of urban transport in the city of Chillán, Chile
}

\author{
O. F. Carvacho ${ }^{1}$, J. E. Celis ${ }^{2}$, K. Trzepla-Nabaglo ${ }^{1}$, \\ L. L. Ashbaugh ${ }^{1} \&$ R. G. Flocchini ${ }^{1}$ \\ ${ }^{I}$ Crocker Nuclear Laboratory, University of California, Davis, USA \\ ${ }^{2}$ Universidad de Concepción Facultad de Medicina Veterinaria, \\ Chillán, Chile
}

\begin{abstract}
Transportation is widely recognized to be a significant and increasing source of air pollution. In the city of Chillán there are many public cars, buses and trucks that have been retired from circulation in the metropolitan region (capital city of Santiago) due to strict regulation from local environmental authorities. In order to study air pollution in Chillán, a typical semi-agricultural central valley city located in the southern Bio-Bio Region of Chile, an aerosol monitoring study was established to measure ambient aerosol composition. The contributions of private cars, public cars, buses and delivery trucks were examined at a sampling site located downtown. The aerosol monitor was operated from September 2001 to September 2002. The study employed an IMPROVE $\mathrm{PM}_{10}$ sampler with Anderson inlet at 3 meters above ground collecting $\mathrm{PM}_{10}$ on Teflon membrane filter, nylon and quartz filter.

Sulfate concentrations were lower than soil, nitrate, elemental and organic carbon, which contributed significantly to $\mathrm{PM}_{10}$ mass. Soil accounted for $25 \%$ of the $\mathrm{PM}_{10}$ mass and carbon particles accounted for just over 50\%. Transportation sources appear to be primary sources of the carbon and soil particles. The remaining mass was mostly secondary ammonium nitrate and ammonium sulfate. Some metals, such as $\mathrm{V}, \mathrm{Ni}, \mathrm{Br}$, and $\mathrm{Pb}$, were measured frequently at the downtown site. They did not contribute appreciably to the $\mathrm{PM}_{10}$ mass, but underscore the importance of transportation sources to measured particulate matter.
\end{abstract}

Keywords: $P M_{10}$, aerosol speciation, sulfate, nitrate, organic and elemental carbon, elemental concentrations, soil. 


\section{Introduction}

Transportation sources are widely recognized to be a significant and increasing source of air pollution world wide. Several reviews have focused on individual modes of transportation and/or single environmental impacts of transportation, e.g. R.N. Colvile et al. [1]. The chemical composition of particulate matter in polluted atmospheres has long been of interest, and has taken on additional importance as its role in human health effects has come under scrutiny. Laden et al. [2] found a strong association between traffic generated particles and increased human mortality in six U.S cities. There was either no association or a slight negative association between crustal (soil) particles and increased mortality in the Laden study. Katsouyanni et al. [3] also found an enhanced effect of traffic on mortality in Europe. According to Harrison et al. [4] road traffic emissions in the UK are well represented by elemental carbon.

Most air pollution studies in Chile have been done in the Santiago urban area, which suffers from heavy air pollution during the winter season [5-7]. Chile is a long narrow country bordered by the Pacific Ocean. It has a Central Valley in the north-south direction, with the Andes Mountains along the east and the Coast Mountains along the west.

Between September 2001 and August 2002, inhalable particulate matter $\mathrm{PM}_{10}$ samples were collected at the center of the city of Chillán, which is located about $400 \mathrm{~km}$ south of Santiago, Chile.

The city presents a central square of 168 hectares, in a style typical of a colonial city, and is one of the Chilean intermediate cities that have experienced a significant urban growth in the last decades. It currently has a population of 200,000. The geographic and traffic characteristics of Chillán are such that the particulate matter in the central area of the city comes principally from mobile sources (urban transport), and the city of Chillán has one of the largest transportation fleets in proportion to its population. Simultaneously, the fleet turns out to be very polluting, since it is composed largely of vehicles that have been withdrawn from circulation in Santiago [8, 9]. This study is an effort to evaluate the aerosol concentration and composition in the city of Chillán, Chile. Additional work is required to understand the size distribution, meteorological effects and other factors.

\section{Method}

Ambient $\mathrm{PM}_{10}$ sampling was conducted every day in downtown Chillán for a period of one year (September 2001 to August 2002). The $\mathrm{PM}_{10}$ concentrations were measured using an IMPROVE sampler (Interagency Monitoring of Protected Visual Environments) with an Anderson $\mathrm{PM}_{10}$ inlet 3 meter from the ground to collect $\mathrm{PM}_{10}$ particles on $25 \mathrm{~mm}$ Teflon membrane filters at a flow rate of $16.7 \mathrm{lpm}$.

The sampler was positioned in the center of the city, as shown in Figure 1, to sample emissions from traffic and stationary sources that significantly contribute to the $\mathrm{PM}_{10}$ concentration within the city. 
The aerosol mass concentration was calculated using the gravimetric method. Teflon filters were weighed before and after each sampling period. The concentrations of 22 elements were determined using energy dispersive X-ray fluorescence spectroscopy at the Natural Resources Laboratory of the University of Concepción, Concepción, Chile.

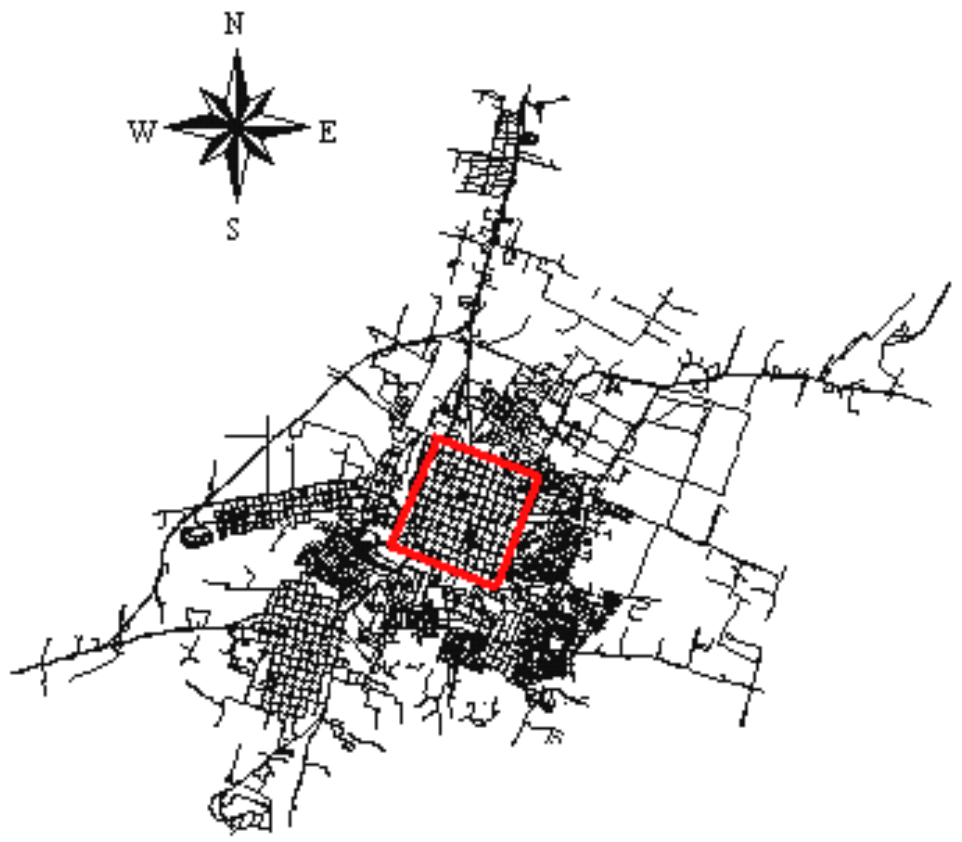

Figure 1: Plan map of the city of Chillán, showing the central square where the PM10 monitor was located.

A soil parameter was calculated from the elemental concentrations by adding the contributions of the geological elements measured by EDXRF in their typical oxide forms, as follows $[10,11]$ :

$$
\text { Soil }=2.20 \times(\mathrm{Al})+2.49 \times(\mathrm{Si})+1.63 \times(\mathrm{Ca})+2.42 \times(\mathrm{Fe})+1.94 \times(\mathrm{Ti})
$$

Quartz filters were used to determine organic carbon (OC) and elemental carbon (EC) by thermal optical reflectance using a DRI model 4000X analyzer. Organic carbon and elemental carbon (OC and EC) are usually concentrated in the fine part of the aerosol and typically constitute a significant fraction of the total particle mass, especially in urban areas [12].

Soil and smoke are the only significant sources of potassium (K). Soil potassium can be present in both $\mathrm{PM}_{10}$ and $\mathrm{PM}_{2.5}$ samples, but potassium from smoke is present almost exclusively in the fine $\left(\mathrm{PM}_{2.5}\right)$ mode. The $\mathrm{K} / \mathrm{Fe}$ ratio in coarse particles, then, can be used to find the excess potassium from smoke 
impact in fine particles $[10,11]$. Eldred [11] developed the following equation, used here, to calculate concentrations of non-crustal smoke potassium [K'] in fine particles.

$$
\left[\mathrm{K}^{\prime}\right]=[\mathrm{K}]-0.6^{*}[\mathrm{Fe}]
$$

The mass concentration of organic matter (OM) was obtained by multiplying the measured OC by a factor of 1.4 [13]. Nylon filters were used to measure ammonium $\left(\mathrm{NH}_{4}^{+}\right)$on a Perkin Elmer Lambda 2 spectrometer. As suggested by Chow and Watson [14], the nitrate $\left(\mathrm{NO}_{3}{ }^{-}\right)$, sulfate $\left(\mathrm{SO}_{4}{ }^{-}\right)$and chloride $\left(\mathrm{Cl}^{-}\right)$ concentrations were determined by ion chromatography on a Dionex DX 100 ion chromatograph. All the analyses were performed at the Natural Resources Laboratory of the University of Concepción, Concepción, Chile.

\section{Results}

The monthly means of the daily $\mathrm{PM}_{10}$ mass concentrations in downtown Chillán city are shown in Figure 2. The mean $\mathrm{PM}_{10}$ concentration was $102.4 \mu \mathrm{g} / \mathrm{m}^{3}$, with a maximum of $147.5 \mu \mathrm{g} / \mathrm{m}^{3}$ in June and a minimum of $73.7 \mu \mathrm{g} / \mathrm{m}^{3}$ in October/ November. To put this in perspective, the annual average $\mathrm{PM}_{10}$ in downtown Santiago is somewhat higher, at $148.4 \mu \mathrm{g} / \mathrm{m}^{3}$ [5]. Furthermore, the 24-hour standard for $\mathrm{PM}_{10}$ mass in Chile is $150 \mu \mathrm{g} / \mathrm{m}^{3}$.

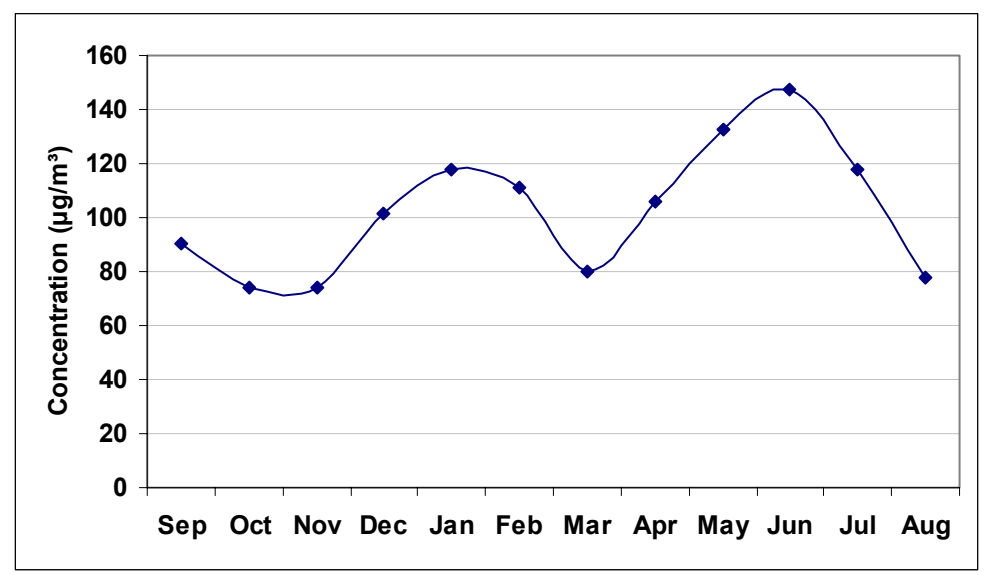

Figure 2: $\quad$ Monthly $\mathrm{PM}_{10}$ concentration in downtown Chillán city from 2001 to 2002 .

The average monthly $\mathrm{PM}_{10}$ concentrations downtown were clearly higher during the cold season (March - August) than during the warmer months (September - February). The maximum $\mathrm{PM}_{10}$ concentrations were in June 2001.

Direct traffic emissions were indicated by the presence of $\mathrm{Pb}$ and $\mathrm{Br}$ in the measured elements. Using the MOVES2 source profile from the California Environmental Protection Agency [15], the observed levels of $\mathrm{Pb}$ and $\mathrm{Br}$ implied 
that the motor vehicles accounted for $5.4 \mu \mathrm{g} / \mathrm{m}^{3}$, or $5.2 \%$, of the measured $\mathrm{PM}_{10}$ mass. The presence of several trace metals, including $\mathrm{Mn}, \mathrm{Zn}, \mathrm{Cu}, \mathrm{As}$, and $\mathrm{Sr}$, in our samples is important, as shown in Figure 3.

Some metals, most notably $\mathrm{Pb}, \mathrm{Mn}, \mathrm{Se}, \mathrm{Ni}, \mathrm{V}$, and $\mathrm{Br}$, varied seasonally. All components from mobile sources increased in the fall and winter and were lower in spring and summer.
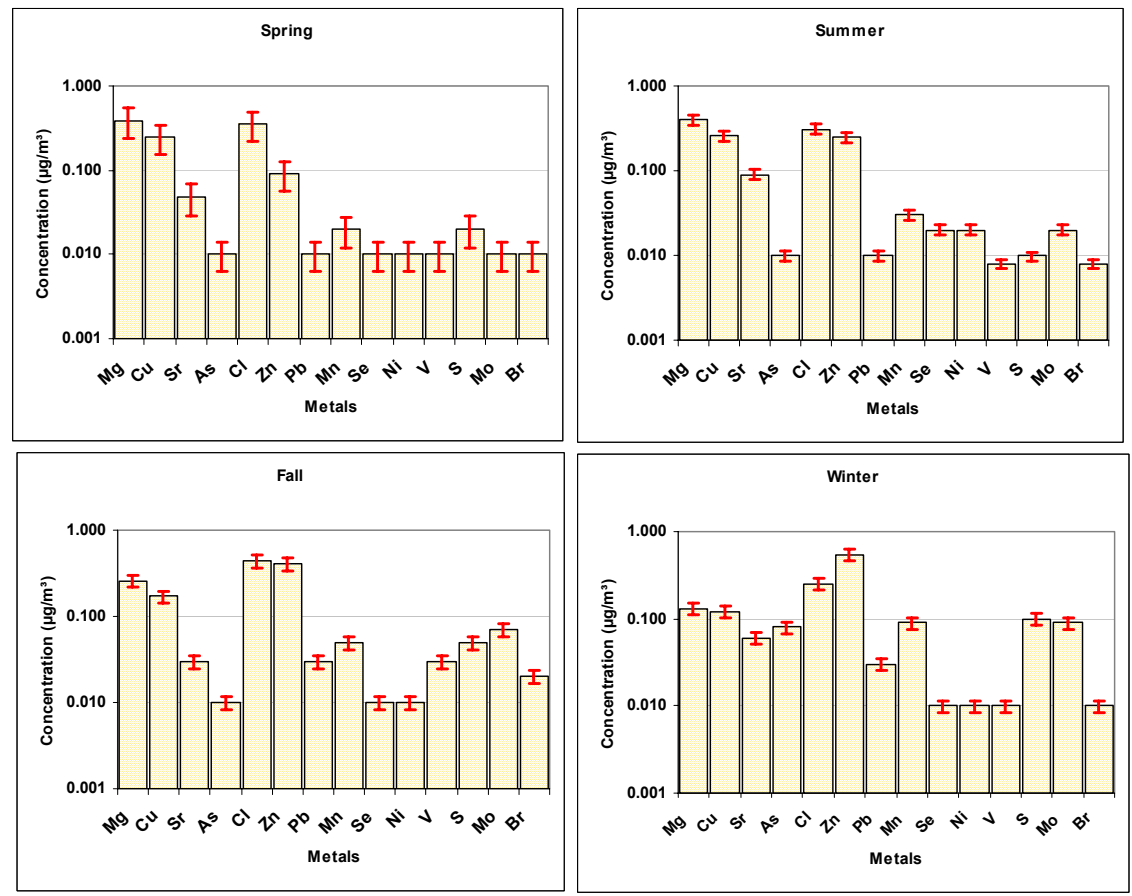

Figure 3: $\quad$ Seasonal average elemental composition for aerosol from 2001 to 2002 at the Chillán downtown sampling site.

Methylcyclopentadienyl manganese tricarbonyl (MMT) is an organic derivative of manganese (Mn) used in unleaded gasoline as an antiknock agent [16]. Its use has increased substantially and its combustion leads to the formation of oxides of manganese $(99.9 \%)$, especially manganese tetraoxide or hausmannite $\left(\mathrm{Mn}_{3} \mathrm{O}_{4}\right)$. With the potential emission and toxicity of $\mathrm{Mn}$ oxides, it is important to evaluate the evolution of Mn concentrations in urban areas [17]. The $\mathrm{Mn}$ and $\mathrm{Pb}$ concentrations track each other, as shown in Figure 4. It is necessary to emphasize that the Chilean Petroleum Company eliminated the use of lead in gasoline by March 2001. For that reason the measured lead levels in this study were lower than the levels found in a preliminary study performed in 1998 in the city of Chillán [9], but gasoline with lead additive is still in use in Chile. The seasonal trend of $\mathrm{Mn}$ and $\mathrm{Pb}$ is consistent with mobile source emissions mixing in a smaller volume in winter, when mixing heights are lower. 


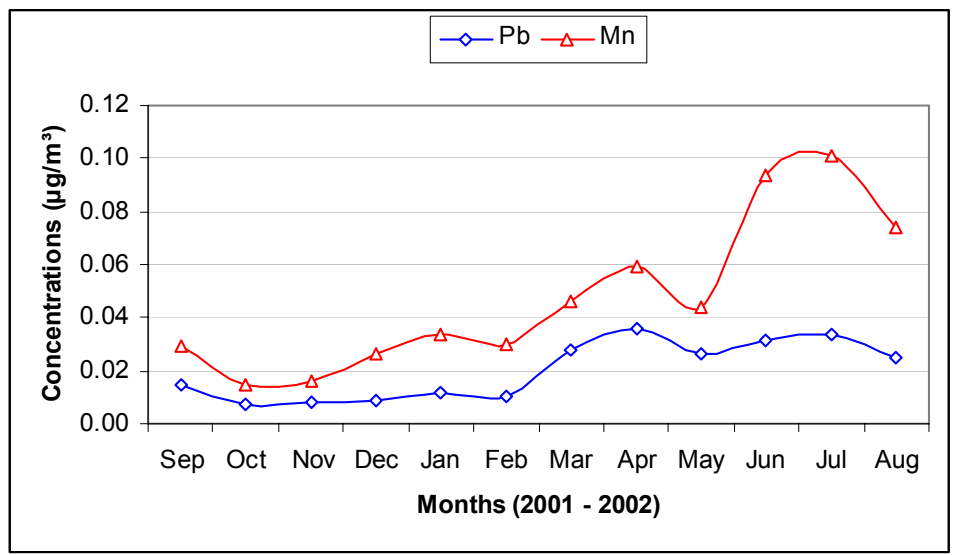

Figure 4: Annual average concentration of $\mathrm{Mn}$ and $\mathrm{Pb}$ from 2001 to 2002 at Chillán downtown sampling site.

The main aerosol particle sources in Chillán are organic matter, probably contributed by transportation sources in the city. These sources accounted for $38.6 \mu \mathrm{g} / \mathrm{m}^{3}$, or $37.7 \%$ of the $\mathrm{PM}_{10}$ aerosol mass. Total elemental carbon is the summation of EC from mobile sources and stationary sources such as wood burning. Using the $\mathrm{K} / \mathrm{Fe}$ ratio and modelling by regression we can estimate the elemental carbon from wood burning. Elemental carbon concentration for the study period accounted for $9.6 \mu \mathrm{g} / \mathrm{m}^{3}$, or $9.4 \%$ of $\mathrm{PM}_{10}$ mass, and the elemental carbon concentration from wood burning was estimated at $1.2 \mu \mathrm{g} / \mathrm{m}^{3}$, or $1.2 \%$. As shown in Figure 5, OM, EC and EC/wood concentrations are higher during the winter time due to the use of wood combustion for house heating.

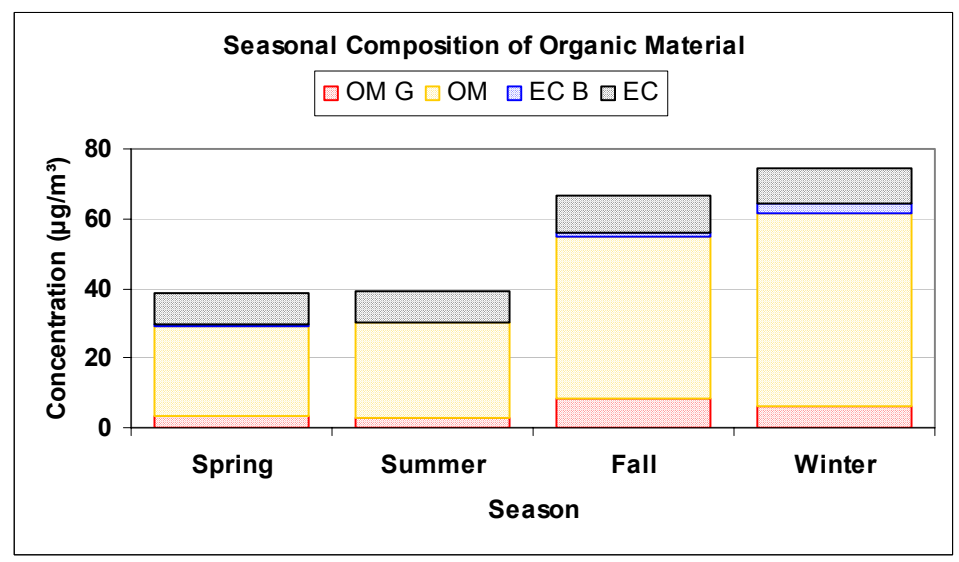

Figure 5: Seasonal averages of Organic Mass (OM), Organic from leaded gasoline (OM G), Elemental Carbon (EC), and Elemental Carbon from wood burning (EC B). 
Combining the above analyses for each season, we can see the composition of the $\mathrm{PM}_{10}$ aerosol in relation to the total $\mathrm{PM}_{10}$ mass. Figure 6 shows that the soil component accounts for half of the aerosol mass in summer, reaches a minimum of $6 \%$ in winter, and is high in spring at $30 \%$ of the mass. Organic material is nearly half of the mass in winter and fall, is lowest in summer at about $25 \%$, and is over a third of the $\mathrm{PM}_{10}$ mass in spring. The contribution to organic mass from leaded gasoline ranges from $3 \%$ in summer to $8 \%$ in fall. Elemental carbon accounts for another $8-12 \%$ of mass, depending on the season. Secondary inorganic particles are highest in fall and winter, as evidenced by ammonium, nitrate, and sulfate. These three ions account for $28 \%$ of mass in fall and winter, but only $13 \%$ in summer.
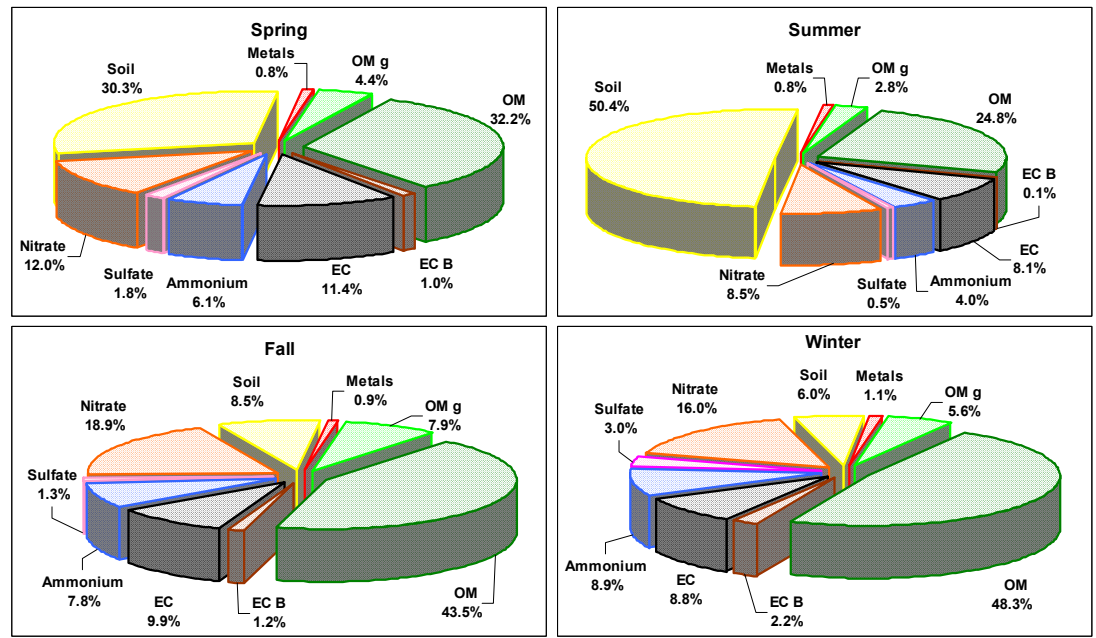

Figure 6: Percentage contributions of components to the total mass of $\mathrm{PM}_{10}$ in Chillán, by season.

\section{Conclusions}

Monthly mean $\mathrm{PM}_{10}$ mass concentrations in Chillán, Chile averaged just over $100 \mu \mathrm{g} / \mathrm{m}^{3}$, with a minimum of $74 \mu \mathrm{g} / \mathrm{m}^{3}$ and a maximum of $148 \mu \mathrm{g} / \mathrm{m}^{3}$, during the one-year sampling period studied. This is lower than the annual average $\mathrm{PM}_{10}$ concentration in downtown Santiago, at $148.4 \mu \mathrm{g} / \mathrm{m}^{3}$. The $\mathrm{PM}_{10}$ in Chillán is dominated by organic particles, most likely from transportation sources. There is a seasonal contribution from wood burning for home heating, but it is quite small. Organic and elemental carbon particles account for approximately half or more of the $\mathrm{PM}_{10}$ mass during much of the year. Soil particles comprise another one-fourth, and secondary ammonium nitrate and ammonium sulfate form another one-fourth. The soil particles are most likely resuspended from city streets by vehicular traffic, making transportation sources accountable for approximately $74 \%$ of Chillán's $\mathrm{PM}_{10}$ pollution. Trace metals are observed in measurable amounts, and might be useful for source apportionment. 


\section{References}

[1] Colvile, R.N., Hutchinson, E.J., Mindell, J.S., Warren, R.F. The transport sector as a source of air pollution. Atmospheric Environment (35) pp. 1537-1565, 2001.

[2] Laden, F., Neas, L.M., Dockery, D.W., Schwartz, J. Association of fine particulate matter from different sources with daily mortality in six U.S. cities. Environmental Health Perspectives (108), pp. 941-947, 2000.

[3] Katsouyanni, K., Touloumi, G., Samoli, E., Gryparis, A., Le Terte, A., Monopolis, Y. Confounding and effect modification in the short-term effect of ambient particles on total mortality: results from 29 cities within the APHEA2 project. Epidemiology (12) pp. 521-531, 2001.

[4] Harrison, R. M., Jones, A. M., Lawrence, R. G. Major component composition of $\mathrm{PM}_{10}$ and $\mathrm{PM}_{2.5}$ from roadside and urban background sites. Atmospheric Environment (38) pp. 4531-4538, 2004.

[5] Artaxo, P., Oyola, P., Martinez, R. Aerosol composition and source apportionment in Santiago de Chile. Nuclear Instruments and Methods in Physics Research B (150) pp. 409-416, 1999.

[6] Rojas, M. C., Artaxo, P., Van Grieken, R. Aerosols in Santiago de Chile: A study using receptor modelling with $\mathrm{X}$-ray fluorescence and single particle analysis. Atmospheric Environment B (24) pp. 227-241, 1990.

[7] Jorquera, H., Palma, W., Tapia, J. An intervention analysis of air quality data at Santiago, Chile. Atmospheric Environment (34) pp. 4073 - 4084, 2000.

[8] Celis, J., Morales, R., Zaror, C., Inzunza, J., Flocchini, R.G., Carvacho, O.F. Chemical characterization of the inhalable particulate matter in the city of Chillan, Chile. J. Chil. Chem. Soc., 48(2) pp. 49-55 2003.

[9] Carvacho, O., Trzepla-Nabaglo, K., Ashbaugh, L., Flocchini, R., Celis, J., Melin, P. Elemental composition of springtime aerosol in Chillán, Chile. Atmospheric Environment (38) pp. 5349-5352, 2004.

[10] Eldred, R.A., Cahill, T. A., Feeney, P.J. Particulate monitoring at U.S. national parks using PIXE. Nuclear Instrumentation and Methods in Physics Research B (22) pp. 289-295, 1987.

[11] Eldred, R.A., Cahill, T.A., Wilkinson, L.K., and Feeney, P.J. Particulate characterization at remote sites across the U.S.: First year results of the NPS/IMPROVE network. Air Waste Manage. Assoc. 82nd Annual Meeting \& Exhibition Anaheim, California June 25-30. Paper 89-151.3, 1989.

[12] Castro, L.M., Pio, C.A., Harrison, R.M., Smith, D.J.T. Carbonaceous aerosol in urban and rural European atmospheres: estimation of secondary organic carbon concentrations, Atmospheric Environment pp. 2771-2781, 1999.

[13] Eldred, R.A.; Cahill, T.A.; Flocchini, R.G. Composition of $\mathrm{PM}_{2.5}$ and $\mathrm{PM}_{10}$ aerosols in the IMPROVE Network. J. Air Waste Manage. Assoc. (47) pp. 194-203, 1997. 
[14] Chow, J, Watson, J. Elemental analysis of airborne particles, Landsbergers, S., and Creatchman, M. editors. Newark, NJ: Gordon and Breach, pp. 97-137, 1999.

[15] California Environmental Protection Agency. 1993. Particulate and gaseous organic receptor modelling for the Southern California Air Quality study. Contract No. A832-132, Final report, November 1993.

[16] Cooper, W.C. The health implications of increased manganese in the environment resulting from the combustion of fuel additives: a review of literature. J. Toxicol. Envir. Hlth. (14) pp. 23-46, 1984.

[17] Loranger, S., and Zayed, J. Manganese and lead concentrations in ambient air and emission rates from unleaded and leaded gasoline between 1981 and 1992 in Canada: A comparative study. Atmospheric Environment (28) No. 9, pp. 1645-1651, 1994.

[18] Sheffield, A.E., Gordon, G.E., Currie, L.A. Riederer, G.E. Organic, elemental, and isotopic tracer of air pollution sources in Albuquerque, NM. Atmospheric Environment (28) No. 8, pp. 1371-1384, 1994. 